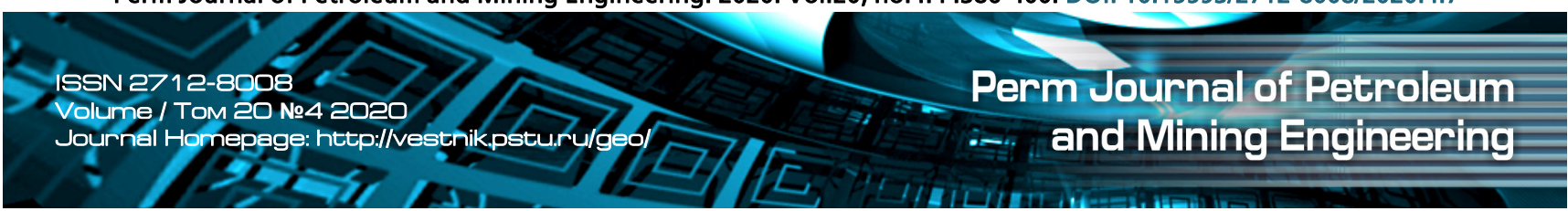

UDC 622.276.6

Review / Обзор

(c) PNRPU / ПНИПУ, 2020

\title{
Application of Integrated Modeling in the Oil and Gas Industry
}

\section{Evgeny V. Filippov ${ }^{1}$, Gennady N. Chumakov ${ }^{2}$, Inna N. Ponomareva ${ }^{3}$, Dmitry A. Martyushev ${ }^{3}$}

${ }^{1}$ LLC LUKOIL-PERM (62 Lenina st., Perm, 614990, Russian Federation)

${ }^{2}$ LLC IC SIBINTEK (building 1, 1 Zagorodnoe highway, Moscow, 117152, Russian Federation)

${ }^{3}$ Perm National Research Polytechnic University (29 Komsomolskiy av., Perm, 614990, Russian Federation)

\section{Применение интегрированного моделирования в нефтегазовой отрасли}

\section{Е.В. Филиппов ${ }^{1}$, Г.Н. Чумаков ${ }^{2}$, И.Н. Пономарева ${ }^{3}$, Д.А. Мартюшев ${ }^{3}$}

${ }^{1}$ ООО «ЛУКОЙЛ-ПЕРМЬ» (Россия, 614990, г. Пермь, ул. Ленина, 62)

${ }^{2}$ ООО ИК «СИБИНТЕК» (Россия, 117152, г. Москва, Загородное шоссе, 1, корп. 1)

${ }^{3}$ Пермский национальный исследовательский политехнический университет (Россия, 614990, г. Пермь, Комсомольский пр., 29)

\section{Received / Получена: 09.04.2020. Accepted / Принята: 25.08.2020. Published / Опубликована: 26.10.2020}

Keywords:

oil industry, complicated well stock, automation,

intellectualization, component models, well operating practices, withdrawal rate, development system optimization, well lift method, bottomhole pressure, reservoir pressure, technological effect, material balance,

hydrodynamic model, geological and technical actions.

\section{Ключевые слова}

нефтяная промышленность, осложненный фонд,

автоматизация,

интеллектуализация, моделикомпоненты, технологические режимы скважин, уровень отборов, оптимизация системь разработки, способ эксплуатации скважин, забойное давление, пластовое давление, технологический эффект, материальный баланс, гидродинамическая модель геолого-технические мероприятия.
The present stage of the oil industry development is characterized by a growing share of hard to reach reserves, the amount of complicated well stock, oil production costs and increasing requirements to production accounting accuracy, implementation of energy-efficient and resource-efficient technologies for development and production, in conditions of the multifactorial evaluation of asset development prospects a problem of the asset intellectualization is a priority. Within this problem, evaluation of asset development prospects a problem of the asset intellectualization is a priority. Within this problem,
automation and implementation of integrated approaches to production optimization, prevention and control of difficulties, effective asset development management both on operative and long-term levels are considered. At present, a complex and effective tool in resolving the problem is an integrated model, i.e. a model of a well production process (oil, gas, water), including all production chain elements in the form of consequential component models. An integrated simulation is effectively used in operational activities of LUKOIL-PERM LLC and is an optimal tool to solve multidisciplinary tasks in field development and technology of oil and gas production, transportation and processing (using software by Petroleum Experts company). Experience of implementing the integrated simulations suggests a synergetic effect related to a need in Experts company). Experience of implementing the integrated simulations suggests a synergetic effect related to a need in
developing associated aspects manifesting themselves by improvement of skills of the specialists, improvement of input data developing associated aspects manifesting themselves by improvement of skills of the specialists, improvement of input data
quality and increase of input data volume, improvement of separate component quality during their integration. A set of actions developed and substantiated using the integrated simulations and their separate components resulted in obtaining some additional oil production over 21.9 thou. $t$

На современном этапе развития нефтяной промышленности, характеризующемся ростом доли трудноизвлекаемых запасов, количества скважин осложненного фонда, себестоимости добычи нефти и, как следствие, возрастанием требований к точности учета добычи и применения энерго- и ресурсоэффективных технологий разработки и добычи, в условиях необходимости многофакторности оценки перспектив развития активов на передовые роли выходит задача интеллектуализации промысла. В данной задаче прорабатываются вопросы автоматизации процессов и внедрения интегрированных подходов по оптимизации добычи, предупреждения и борьбы с осложнениями, эффективного управления разработкой активов как на оперативном, так и долгосрочном уровне. Комплексным и эффективным инструментом при решении поставленных задач на сегодняшний день является интегрированная модель, под которой понимается модель процесса добычи скважинной продукции (нефть, газ, вода), включающая в себя все элементы понимается модель процесса добычи скважинной продукции (нефть, газ, вода), включающая в себя все элементы
производственной цепочки в виде последовательно связанных моделей-компонентов. Интегрированное

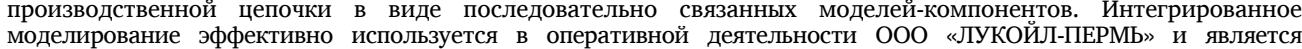
оптимальным инструментом для решения мультидисциплинарных задач в области разработки месторождений и технологии добычи, транспорта и подготовки нефти и газа (используется программное обеспечение компании Petroleum Experts). Опыт применения интегрированных моделей позволяет говорить о синергетическом эффекте, связанном с необходимостью развития сопутствующих направлений и проявляющемся в росте компетенций специалистов, улучшении качества и увеличении объема исходных данных, улучшении качества отдельных специалистов, улучшении качества и увеличении объема исходных данных, улучшении качества отдельных отдельных компонентов комплекс мероприятий позволил получить дополнительную добычу нефти более 21,9 тыс. т. 


\section{Introduction}

The present stage of the oil industry development is characterized by an increased portion of hard-to-recover reserves, amount of complicated wells stock, oil production cost, and as result, higher requirements to production accounting accuracy and implementation of energy- and resource-efficient technologies for development and production, in the conditions of necessity multifactorial evaluations of asset development prospects, a problem of asset intellectualization gains priority. As part of this problem, automation and implementation of the integrated approaches to production optimization, prevention and control of complications, effective asset development management both on operative and long-term levels are considered [1-5]. At present, a complex and effective tool in resolving the problems is an integrated model (IM), being a model of a well production process (oil, gas, water), including all production chain elements in the form of consequential component models: reservoir, wells, collection and transportation systems (CTS), formation pressure maintenance systems (FPM), and a plant [6-14].

The final purpose of IM usage is optimization and improvement of accuracy of forecasting well production, both for long-term, mid-term, and short-term periods, due to the addressed consideration of possible restrictions of the component models and minimization of calculation errors, with a more comprehensive consideration of external factors [15-24].

\section{Application of Integrated Models at the Fields of LUKOIL-PERM, LLC}

An integrated model supposes a set of component models integrated into a single system. Depending on the tasks being solved, an integrated model can include the following components: reservoir model, well model, collection and transportation system model, formation pressure maintenance system model, plant model (preliminary water removal unit, oil processing and pumping unit), export model, economic model. An integrated model mainly differs from applied geological and hydrodynamic models (GHM) in its possibility to consider a well interference not only in the reservoir, but also in the collection and transportation system. This gives an opportunity to evaluate interference of wells, separate well clusters and fields, connected by a single collection system, which supposes a completely new approach to justifying actions implemented at a separate reservoir area, specific well or pipeline section.

At present, LUKOIL-PERM, LLC, build IM (using Petroleum Experts software) in two configurations: well model (Prosper module), collection and transportation system and formation pressure maintenance model (Gap module); reservoir model (Configuration 2 full-scale GHM on software TempestRoxar, EclipseSchlumberger, Configuration 1 material balance model, MbalPetex module); integration of separate modules is enabled through the use of Resolve module. IM in Configuration 1 is updated monthly, while in configuration \#2 the update is once a year. Configuration 1 is used in calculations having duration less a year, Configuration 2 is for mid-term and long-term calculations. The integrated model is a daily usage tool for solving production tasks, which implies more strict requirements to quality of adaptation and adjustments of all components including reservoir models. In particular, the reservoir model is adjusted to operative data (current operation mode), contrary to GHM, gas production and gas factor value are adjusted per each well. During the integration process, the quality of the input data for adjustment of separate components undergoes additional validations through the mutual parameters matching.

Selection of candidate fields for building an IM is based on the oil production volume of the field in the oil production share. At present, LUKOIL-PERM, LLC, has built and operates a unified IM for assets of Oil and Gas Production Division (OGPD) 11, which includes five fields joined into a unified collection system, and an integrated model of two GreenField assets of OGPD 12, where the task of oil production optimization is being successfully rolled out under conditions of gas production limitations. 
LUKOIL-PERM, LLC, has tested the approaches and successfully uses the following calculations with IM:

\section{- in development:}

- formation of optimal process parameters of production well operations (PPPWO), including operation under limitations;

- justification of optimal production rates per wells;

- preparation of operative proposals to optimize formation pressure maintenance systems: justification of optimal injection volumes and injection well operation parameters, justification of new focal points;

- well selection for temporary optimization with the purpose to reduce underruns caused by actions with regard to interference and potentials;

- integrated tasks:

- selection and justification of optimization actions per well;

- justification of the lift methods and well operation practices after well servicing/capital workover;

- calculations of asset interferences over collection and transportation system;

- calculation of asphaltens, resins and paraffins formation ranges in the wellbore.

These calculations are aimed at costs reduction and providing for additional oil production. Main tasks include ensuring the fulfillment of oil production schedules, reduction of production losses on the existing wells stock, finding limitation nodes on the basis of potentials calculations, improvement of production wells stock operation efficiency.

\section{Use of Integrated Model \\ for the Purposes of Development}

Process parameters of production well operations include calculation for the following options: basic (without operating factor) and with integrated plan actions (Fig. 1). The analysis of the latter results in evaluation of losses for the existing stock, and subject to an oil production schedule, a decision is taken whether to implement compensatory actions or not. The actions include temporary activities for the period of a long-term planned shutdown, and coninuous optimizations of production well operating practices. Several optimization options are further calculated, including inter alia geological and technical action plans. However, the process of PPPWO formation always commences with the data collection and IM update.

Approaches to selecting candidate wells for continuous optimization were developed by LUKOIL-PERM, LLC, and provide for well ranging depending on their potential (Fig. 2), which is calculated using the hydrodynamic model (HDM) or IM. This is followed by multiple-option

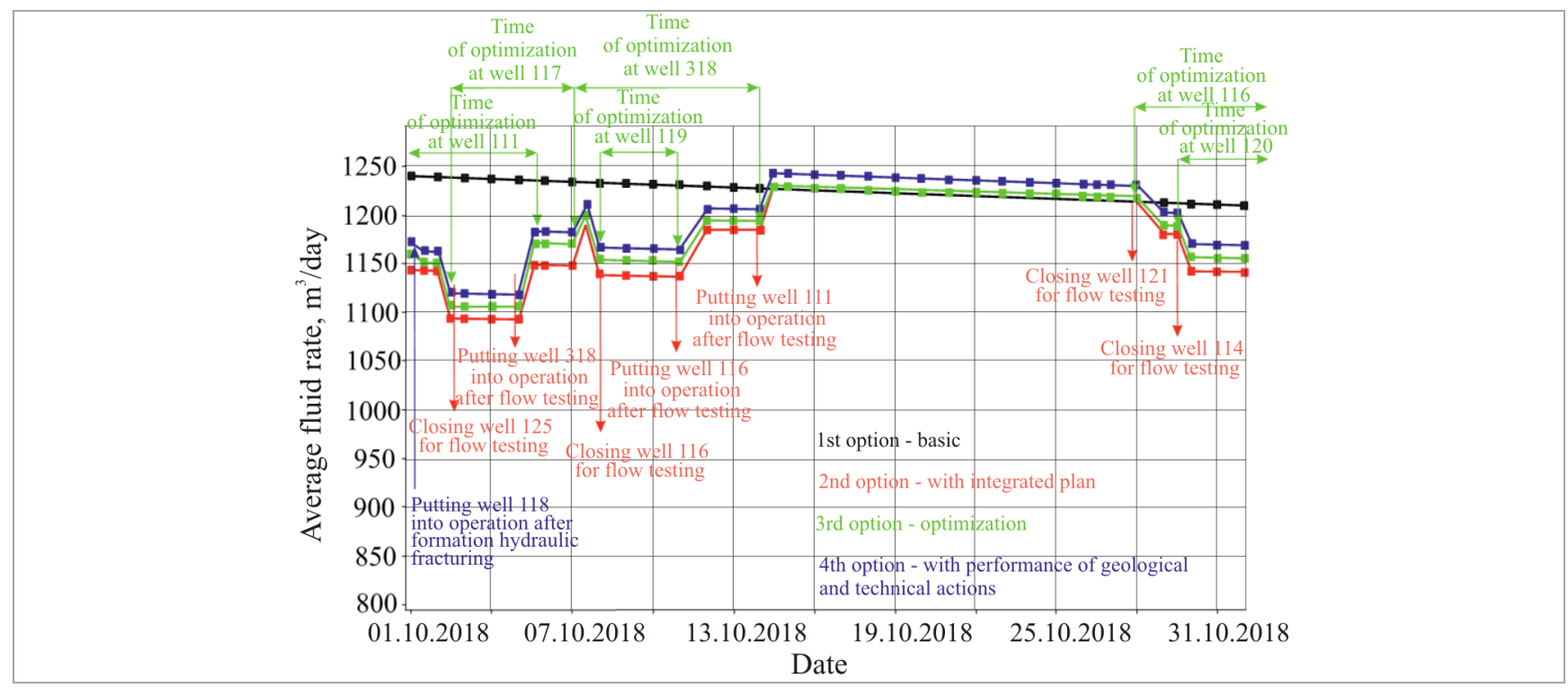

Fig. 1. Example of fluid withdrawal calculation as part of PPPWO formation for the field using IM 
calculations using IM with increased withdrawals and monitoring of rate dynamics, reservoir and bottom hole pressures by drainage areas of candidate wells for a given period. The period is a design time of the pump operation to failure at given frequencies of electric-centrifugal pumps (ESP). Based on the analysis results, for the purposes of the performance optimization, a list of candidate wells with optimal fluid rates with the reference to the corresponding ESP operation frequencies is made. Further candidates are selected with regard to risks assessement and results of the integrated geological analysis of asset developments.

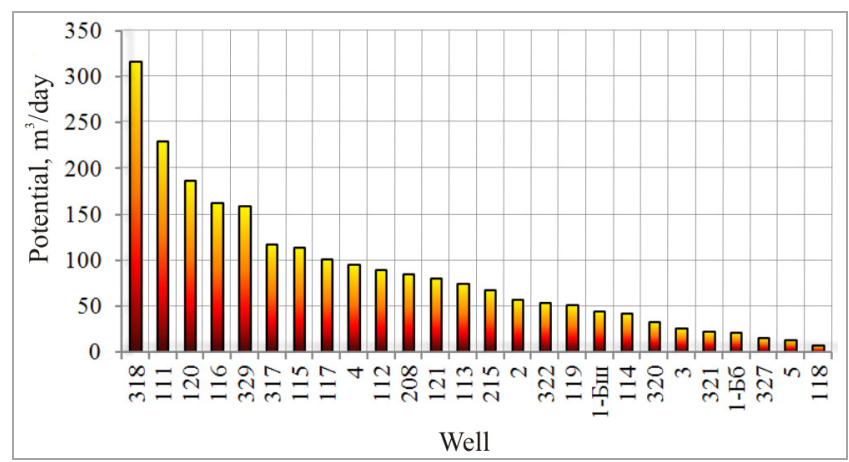

Fig. 2. Example of well rating per value of their potential
All candidates for production parameters optimization are reviewed using this approach. In 2017-2018, 12 actions were selected and completed using this aproach with the cumulative technological effect exceeding 10.3 thou. t. of additional oil production.

The selection of wells for temporary optimization is performed with regard to potentials, determined by a long-term closing of surrounding wells having hydrodynamic connectivity with operating wells. The interference is established using the hydrodynamic models (Table) between the producing wells of an asset covered by the integrated models. The calculations result in the list of candidate wells for a temporary optimization and their operation practices calculated using well models. The described implementation of the emerging potential enables to partially compensate oil losses during a well shutdown for flow testing or long-term workovers without significant damages to energy characteristics of areas of their disposition.

The cumulative technological effect from temporary optimization performance exceeded 5.4 thou. $\mathrm{t}$ in 2017-2018.

Matrix of interference between producing wells of a development asset

\begin{tabular}{|c|c|c|c|c|c|c|c|c|c|c|c|c|c|}
\hline \multirow{2}{*}{ Closed well } & \multirow{2}{*}{ Reactive wells } & \multicolumn{12}{|c|}{ Fluid rate increase during first month, $\mathrm{m}^{3} /$ day } \\
\hline & & 1 & 5 & 111 & 112 & 113 & 208 & 215 & 317 & 318 & 320 & 329 & Total \\
\hline 1 & $\begin{array}{l}111,112,113, \\
215,317,318 \\
\end{array}$ & - & 0 & 0.17 & 0.16 & 0.29 & 0 & 0.06 & 0.94 & 0.32 & 0 & 0 & 1.94 \\
\hline 5 & - & 0 & - & 0 & 0 & 0 & 0 & 0 & 0 & 0 & 0 & 0 & 0 \\
\hline 111 & $\begin{array}{c}1,112,113, \\
317,318,329\end{array}$ & 0.09 & 0 & - & 0 & 0.03 & 0 & 0 & 0.42 & 2.69 & 0 & 0.37 & 3.6 \\
\hline 112 & $\begin{array}{c}1,113,215 \\
317,318\end{array}$ & 0.14 & 0 & 0 & - & 5.83 & 0 & 3.06 & 0.07 & 0.09 & 0 & 0 & 9.19 \\
\hline 113 & $\begin{array}{c}1,111,112, \\
215,317,318\end{array}$ & 0.43 & 0 & 0 & 10.87 & - & 0 & 2.98 & 0.25 & 0.19 & 0 & 0 & 14.72 \\
\hline 208 & 215,320 & 0 & 0 & 0 & 0 & 0 & - & 0 & 0 & 0 & 0.64 & 0 & 0.64 \\
\hline 215 & $\begin{array}{c}1,111,112,113, \\
208,317,318\end{array}$ & 0.15 & 0 & 0 & 6.12 & 2.96 & 0 & - & 0.06 & 1 & 0 & 0 & 10.29 \\
\hline 317 & $\begin{array}{c}1,111,112,113 \\
215,318,329\end{array}$ & 0.86 & 0 & 0.94 & 0.09 & 0.21 & 0 & 0.01 & - & 0.17 & 0 & 0.03 & 2.31 \\
\hline 318 & $\begin{array}{c}1,111,112,113, \\
215,317,329\end{array}$ & 0.09 & 0 & 1.08 & 0.05 & 0.05 & 0 & 0.16 & 0.05 & - & 0 & 0.05 & 1.53 \\
\hline 320 & $112,208,215$ & 0 & 0 & 0 & 0 & 0 & 0.51 & 0 & 0 & 0 & - & 0 & 0.51 \\
\hline 329 & 111,318 & 0 & 0 & 0.29 & 0 & 0 & 0 & 0 & 0 & 0 & 0 & - & 0.29 \\
\hline
\end{tabular}

N o t e: the green color shows wells with the maximal fluid rate increase; the sand color shows wells with a medium fluid rate increase; the purple color shows the wells with the minimal fluid rate increase. 
One more task to be resolved as part of PPPWO formation using IM, is justification of withdrawal redistribution between wells subject to the reservior area, and also between assets, while maintaining target withdrawal level due to evaluation of actual and calculated reservoir pressure dynamics within the calculated period in addition to the well allocation, plans on FPM system optimization with the purpose to preserve the deposit energy characteristics. The effectiveness of this decision is confirmed both by long-term calculation results and analysis of actual dynamics of reservoir and bottomhole pressures of the production assets before and after implementation of the approach. For example, the above operation algorithm has been used at one of fields owned by LUKOIL-PERM, LLC, since 2016, which resuted in more than two times decline in the rate of reservoir pressure (Fig. 3), while production wells bottomhole pressures were successfully stabilized.

Overall, the described approaches allow us not only to form adequate and justified PPPWO for the next month, but also promptly manage field developments by solving tasks of forecasting oil production levels, planning losses on existing well stock, effectively using potential for compensation of losses at the existing well stock and managing utilization factor.

As part of preparing operative proposals on FPM system optimization, the following tasks are solved: putting into operation top priority flood focal points under conditions of a fast reservoir pressure drop at the developed assets, plans of their putting into operation subject to shortage of the injection water available and evaluation of the flood focal point organization efficiency according to design solutions.

Both tasks are solved by performing multipleoption calculations using IM. In addition, the following parameters were changed: probable candidate wells to be transferred to injection wells, well injectivity with regard to existing restrictions on volume of water source wells production. In total over 150 calculations were performed, according to the results of which options with the best performance indicators were proposed and implemented.

Actual technological effects of the proposed and based on FPM system actions are quarterly evaluated using HDM according to the developed approach. The approach implies a retrospective calculation within the area with withdrawal rates but no actions will be implemented. However, the bottomhole pressure values will be recorded for each step of wells, equal to actual values, and a comparison of the calculation result with actual production. In general, the effectiveness of actions implemented on assets is confirmed. As of the current date, the technological effect of actions implemented is evaluated at the level of 13 thou. $t$.

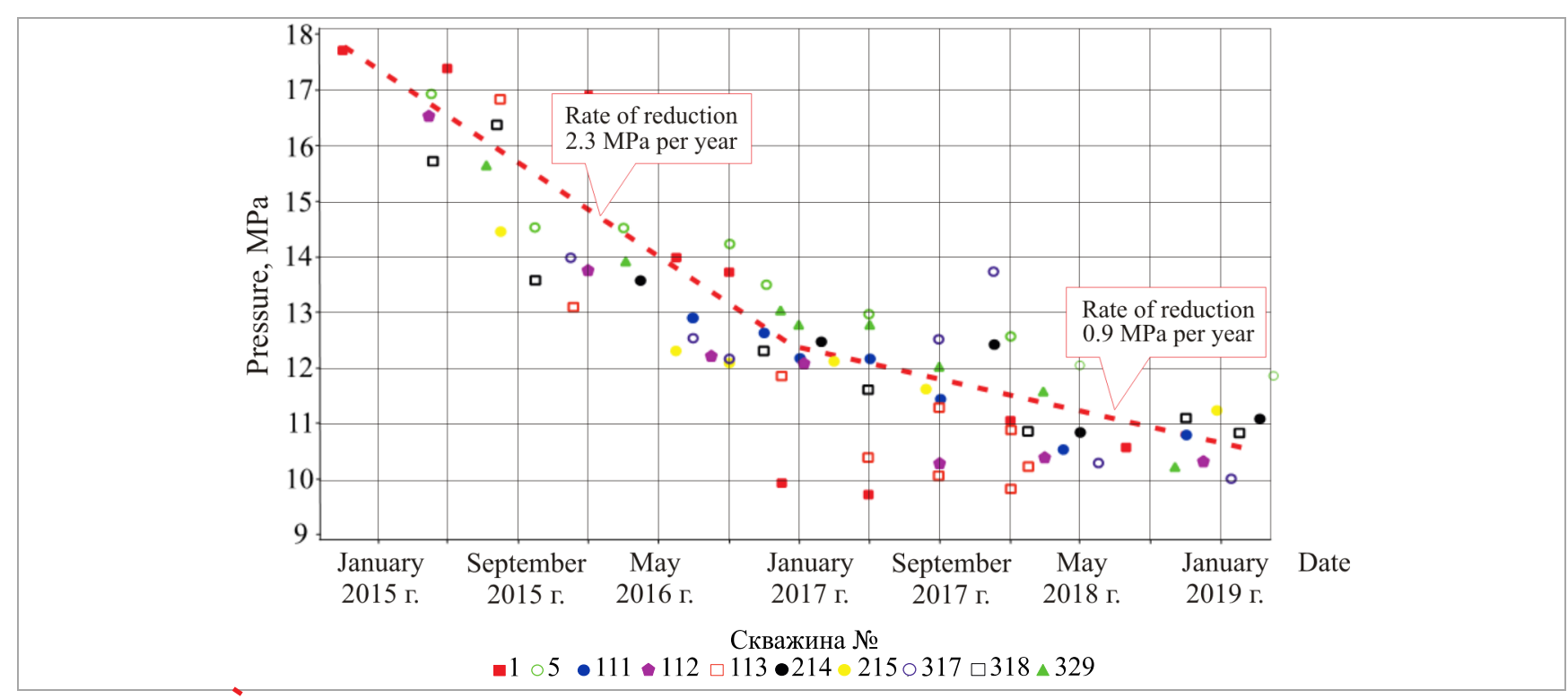

- Fig. 3. Dynamics of reservoir pressure at development asset before and after

$\because \quad$ implementation of the withdrawal redistribution approach 


\section{Solving Integrated Tasks Using Integrated Simulation}

As part of organizing the multidisciplinary approach, LUKOIL-PERM, LLC, justifies the well operation mode and procedures after well servicing or capital workover, that is performing the geological field analysis. The results of the analysis are used for calculations with HDM to determine the optimal rate providing for stable operations of the downhole pumping equipment for a target period of service. Further, the downhole pumping equipment is selected using IM for the calculated optimal rate and bottomhole pressure, with the subsequent analysis of its performability under different conditions for the period of three years (a 10-30 atm drop in the reservoir pressure below the current value, an increase in water contents by $2-20 \%$, changes of frequency in the range of 40-60 Hz) (Fig. 4). The effect of the described approach is balanced 'reservoir - well' nodes, which enables selecting energy-effective equipment, providing for stable operation of the downhole pumping equipment for the forecast period, and providing for operation to the failure time increase.

Using the unified integrated simulation of the group of assets of the oil and gas production department (OGPD-11) LUKOIL-PERM, LLC, solves the problem by evaluating the throughput capacity of active pipelines by fields with regard to asset development, according to actions planned by an industry development program (calculation period of 10 years). Calculation results show that the throughput capacity corresponds to maximal production conditions, pipeline pressure does not exceed maximal design values under condition of maintaining the separation pressure at the ending point of $2.5 \mathrm{~atm}$ at most. However, the interference of the fields through the collection and transportation system is determined. When withdrawal is increased at one of the fields by putting into operation new production drilling wells, the withdrawal decreases at another field working at wellhead pressure in unified gathering and transportation system (without booster pump station). Calculations allowed us

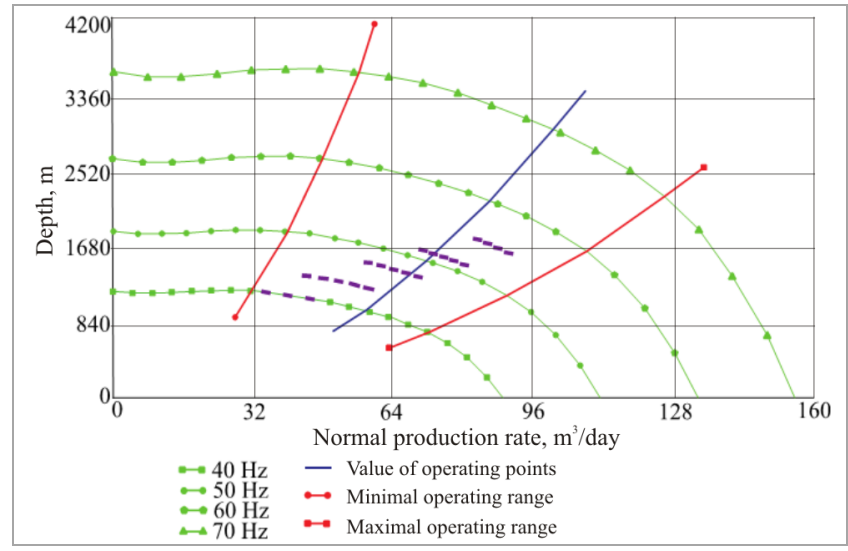

Fig. 4. Comparison of operating points and pump performance data during change of production parameters

to assess the potential level of fluid and oil production loss caused by the system lockup. Various options of compensations of emerging losses were further studied using IM, but the calculation results showed that an increase of the well withdrawal under conditions of pressure rise in the pipeline common for the two fields brings critical pressure increase in oil collection pipelines at the field with the calculated optimization. It is also noted that a withdrawal increase during optimization of well production procedures with to compensate losses caused by the pressure rise in the common pipeline leads to aggravation of energy characteristics of the development assets (field is depleted according to production engineering documentation) and entails additional losses in the long term. Therefore, compensating actions at this field are not recommended. Evaluated potential losses will be considered in preparation of future production plans for this field.

Experience of solving integrated tasks using IM gained by LUKOIL-PERM, LLC, highlights the possibility to account for influence of the separation pressure change on withdrawal at field, group of fields, connected by a single collection system, evaluate interference of fields and substantiate feasibility of upgrading CTS and oil processing at them.

The possibility to use the integrated models to solve applied problems in the operative activities is provided also by toughening requirements to quality of the adjustment of 
separate component models and IM as a whole. In particular, if using 'reservoir' of HDM as the component model in relation to currently used requirements to quality of its adjustment stated in [25], provisions for IM [26] introduce additional requirements to quality of the hydrodynamic model adjustment in aspect of well rates by separate fluids, and in aspect of the associated petroleum gas production levels, including the gas factor values. In addition, requirements to compliance of the cumulative parameters become tougher (from 20 to $5 \%$ ), and the 'corridor' of permitted deviations in reservoir and bottomhole pressures is narrowed more than by two times. In the process of integrating separate IM components, additional verification of the input data takes place, nonphysical adjustment factors are identified, low quality input data are being detected. This results in significant improvement of quality and physical contents of component models. In addition, LUKOIL-PERM, LLC, developed an approach that during adjustments of separate component models with high uncertainty of the input data results of adjustment of other component models are used in cases, when data uncertainty is lower, or where it is possible to redistribute this uncertainty between separate nodes. For example, in adjustment of the component models for the actual gas factor, which is measured 1-2 times per year at most, the component model 'well' has a possibility to use the actual value, while maintaining the physical essence of the model minimum by two factors: gas separation factor at pump intake and pump degradation factor. In addition, adjustment for the actual gas factor in HDM is difficult. Taking this into account, when HDM is satisfactory adjusted using the actual gas factor as of measurement date, it is decided until the next measurement to use the parameter value calculated in HDM during the adjustment of the well models and collection system model. In this case, the reduction of general IM adjustment complexity is observed due to a satisfactory convergence of the reservoir and well models in parameters being adjusted during integration.

The experience of using the integrated models gained by LUKOIL-PERM shows the need to improve competencies of specialists, develop their multidisciplinary knowledge, teach them to solve tasks emerging on the edge of geology, field development and oil and gas production equipment and technology [27-45]. Basic knowledge of specialists dealing solely with hydrodynamic modeling, or having no experience at all with simulators, is not enough for work with high-tech product - integrated simulation. In order to develop corresponding competencies at the present professional development program in "Integrated modeling" is developed on the basis of Perm National Research Polytechnic University.

In is necessary to note that partially an issue of labor efforts on collection and downloading input data for upgrading integrated simulation at present is resolved because of involvement of specialists from Branch of LUKOIL-Engineering, LLC, and PermNIPIneft in Perm to data collection and simulation upgrading process, and also due to application of primary automation means, so-called 'scripts'.

\section{Conclusion}

We can conclude that the integrated model is effectively used in operative activities by LUKOIL-PERM, LLC, and is an optimal tool to solve multidisciplinary tasks in the field development and technology of oil and gas production, transportation and processing. The experience of implementing integrated models suggests the synergetic effect related to the need to develop associated aspects manifesting themselves by improvement of skills of the specialists, improvement of input data quality and increase of input data volume, improvement of separate components quality during their integration. At present "Integrated modeling" direction of "Intellectual field" project acts like an 'engine' in the process of developing tools for simulation, digitalization and automation of an enterprise. A complex of actions developed and substantiated using integrated models and their separate components allowed increasing the oil production by over 21.9 thou. $t$. 


\section{References}

1. Karl W. Bandilla, Bo Guo, Michael A. Celia. Applicability of vertically integrated models for carbo storage modeling in structured heterogeneous domains. Energy Procedia, 2017, vol. 114, pp. 3312-3321. DOI: $10.1016 /$ j.egypro.2017.03.1463

2. Ntlhabane S., Becker M., Charikinya E., Voigt M., Schouwstra R., Bradshaw D. Towards the development of an integrated modelling framework underpinned by mineralogy. Minerals Engineering, 2018, vol. 116, pp. 123-131. DOI: 10.1016/j.mineng.2017.09.013

3. Apasov R.T., Chameev I.L., Varavva A.I., Vernikovskaia O.S., Il'iasov A.R., Virt V.I. Integrirovannoe modelirovanie - instrument povysheniia kachestva proektnykh resheni dlia razrabotki neftianykh otorochek mnogoplastovykh neftegazokondensatnykh mestorozhdenii [Integrated modeling: a tool to improve quality of design solutions in development of oil rims of multi-zone oil-gas-condensate fields]. Neftianoe khoziaistvo, 2018, no. 12, pp. 46-49. DOI: $10.24887 / 0028-2448-2018-12-46-49$

4. Kolmakov A.V., Marishkin V.A., Bordzilovskii A.S., Terent'ev V.L., Fedorov K.M. Monitoring razrabotki mestorozhdenii $\mathrm{s}$ ispol'zovaniem integrirovannogo gidrodinamicheskogo modelirovaniia [Monitoring of field development on the basis of integrated reservoir simulation]. Neftianoe khoziaistvo, 2012, no. 7, pp. 100-102.

5. Burcin Cakir Erdener, Kwabena A. Pambour, Ricardo Bolado Lavin, Berna Dengiz. An integrated simulation model for analyzing electricity and gas systems. International journal of electrical power and energy systems, 2014, vol. 61, pp. 410-420. DOI: $10.1016 /$ j.ijepes.2014.03.052

6. Guan Q., Goharzadeh A., Chai J.C., Vargas F.M., Biswal S.L., Chapman W.G., Zhang M., Yap Y.F. An integrated model for asphaltene deposition in wellbores/pipelines above bubble pressure. Journal of Petroleum Science and Engineering, 2018, vol. 169, pp. 353-373. DOI: $10.1016 /$ j.petrol.2018.05.042
7. Vlasov A.I., Andreev K.V., Kyrnaev D.V. Sovershenstvovanie razrabotki i ekspluatatsii mestorozhdenii putem primeneniia elementov "Intellektual'nogo mestorozhdeniia" [Improving the development and exploitation through the use of elements of Smart field]. Neftianoe khoziaistvo, 2014, no. 3, pp. 68-69.

8. Afanas'eva I.S., Fedorchenko G.D., Kozhemiakin A.A., Smyslov V.A. Prakticheskaia realizatsiia kontseptsii integrirovannogo proektirovaniia dlia shel'fovogo aktiva AO "Zarubezhneft" [Practical implementation of integrated approach concept for offshore assets of Zarubezhneft JSC]. Neftianoe khoziaistvo, 2016, no. 8, pp. 94-97.

9. Jianhong Ye., Jeng D.-S., Chan A.H.C., Wang R., Zhu Q.C. 3D integrated numerical model for Fluid-Structures-Seabed Interaction (FSSI): Loosely deposited seabed foundation. Soil Dynamics and Earthquake Engineering, 2017, vol. 92, pp. 239-252. DOI: $10.1016 /$ j.soildyn.2016.10.026

10. Nait Amar Menad, Zeraibi Noureddine, Abdolhossein Hemmati-Sarapardeh, Shahaboddin Shamshirband. Modeling temperaturebased oil-water relative permeability by integrating advanced intelligent models with grey wolf optimization: Application to thermal enhance oil recovery process. Fuel, 2019, vol. 242, pp. 649-663. DOI: 10.1016/j.fuel.2019.01.047

11. Akhmetzianov Atlas V., Kushner Alexei G., Lychagin Valentin V. Integrable models of oil displacement. IFAC-PapersOnLine, 2015, vol. 48, iss. 3, pp. 1264-1267. DOI: $10.1016 /$ j.ifacol.2015.06.258

12. Horsholt S., Nick H.M., Jorgensen J.B. Oil production optimization of Black-Oil models by integration of Matlab and Eclipse E300. IFAC-Papers Online, 2018, vol. 51, iss. 8, pp. 88-93. DOI: $10.1016 /$ j.ifacol.2018.06.360

13. Cuiwei Liu, Yuxing Li, Minghai $\mathrm{Xu}$ An integrated detection and location model for leakages in liquid pipelines. Journal of Petroleum Science and Engineering, 2019, vol. 175, pp. 852-867. DOI: $10.1016 /$ j.petrol.2018.12.078 
14. Kiril Manevski, Christen D. Borgesen, Xiaoxin Li, Mathias N. Andersen, Per Abrahamsen, Chunsheng $\mathrm{Hu}$, Soren Hansen. Integrated modeling of crop production and nitrate leaching with the Daisy model. Methods', 2016, vol. 3, pp. 350-363. DOI: $10.1016 /$ j.mex.2016.04.008

15. Kovalenko I.V., Vydrin A.G., Semenov A.Iu., Sukhanov A.N., Fedorov M.V. Integrirovannoe modelirovanie razrabotki neftianoi otorochki Pestsovogo mestorozhdeniia [Integrated modeling of the oil rims development of the Pestsovoye field]. Neftianoe khoziaistvo, 2019, no. 2, pp. 49-51. DOI: $10.24887 / 0028-2448-2019-2-49-51$

16. Kudriashov S.I., Afanas'eva I.S., Dashevskii A.V., Kozhemiakin A.A. Integrirovannyi podkhod $\mathrm{k}$ planirovaniiu pokazatelei neftegazodobyvaiushchego predpriiatiia v AO "Zarubezhneft"' [Integrated approach to oil and gas producing enterprise rates planning in Zarubezhneft JSC]. Neftianoe khoziaistvo, 2015, no. 12, pp. 144-148.

17. Kostiuchenko S.V., Kudriashov S.V., Vorob'ev P.V. Integrirovannye modeli dlia proektirovaniia soglasovannykh sistem dobychi i sbora nefti (chast' 1) [Integrated models to design coordinated oil production and gathering systems (part 1)]. Neftianoe khoziaistvo, 2003, no. 11 , pp. 100-103.

18. Gilaev G.G., Manasian A.E., Voropaev A.M., Ismagilov A.F. , Khamitov I.G., Kireev I.I. Opyt kompleksnogo proektirovaniia mestorozhdenii OAO "Samaraneftegaz" [Samaraneftegaz JSC experience in integrated project approach]. Neftianoe khoziaistvo, 2013, no. 3, pp. 54-57.

19. Batrashkin V.P., Ismagilov R.R., Panov R.A., Mozhchil' A.F., Gil'mutdinova N.Z., Dmitriev D.E. Integrirovannoe kontseptual'noe proektirovanie, kak instrument sistemnogo inzhiniringa [The integrated conceptual design as a tool of systematic engineering]. Neftianoe khoziaistvo, 2016, no. 12, pp. 80-83.

20. Ismagilov R.R., Maksimov Iu.V., Ushmaev O.S., Mozhchil' A.F., Gil'mutdinov N.Z. Integrirovannaia model' dlia kompleksnogo upravleniia razrabotkoi i obustroistvom mestorozhdenii [Integrated model for complex management of reservoir engineering and field construction]. Neftianoe khoziaistvo, 2014, no. 12 , pp. 71-73.

21. Panov R.A., Mozhchil' A.F., Dmitriev D.E., Alekseev P.O., El'onyshev A.V., Ashikhmin I.A. Tsifrovoi kontseptual'nyi inzhiniring: avtomatizatsiia razmeshcheniia ob"ektov obustroistva [Digital conceptual engineering: automatization of facilities allocation]. Neftianoe khoziaistvo, 2018, no. 12, pp. 72-75. DOI: $10.24887 / 0028-2448-2018-12-72-75$

22. Silvya Dewi Rahmawati, Curtis Hays Whitson, Bjarne Foss, Arif Kuntadi. Integrated field operation and optimization. Journal of Petroleum Science and Engineering, 2012, vol. 81, pp. 161-170. DOI: $10.1016 /$ j.petrol.2011.12.027

23. Hristo Apostolov, Matthias Fischer, Daniel Olivotti, Sonja Dreyer, Martin Eigner. Modeling framework for integrated, Modelbased development of product-Service systems. Procedia CIRP, 2018, vol. 73, pp. 9-14. DOI: $10.1016 /$ j.procir.2018.03.307

24. Li Qiang, Zhong Haiquan, Wang Yuan, Leng Youheng, Guo Chunqiu. Integrated development optimization model and its solving method of multiple gas fields. Petroleum Exploration and Development, 2016, vol. 43, iss. 2, pp. 293-300. DOI: $10.1016 / S 1876-3804(16) 30033-7$

25. Vremennyi reglament otsenki kachestva i priemki trekhmernykh tsifrovykh geologo-gidrodinamicheskikh modelei, predstavliaemykh pol'zovateliami nedr v sostave tekhnicheskikh proektov razrabotki mestorozhdenii uglevodorodnogo syr'ia na rassmotrenie Tsentral'noi komissii po razrabotke Rosnedra po uglevodorodnomu syr'iu. Priniat na rasshirennom zasedanii Tsentral'noi komissii po razrabotke Rosnedra po uglevodorodnomu syr'iu ot 19.04.2012, № 5370, vvoditsia $\mathrm{v}$ deistvie s 01.07.2012 [Temporary regulations for assessing the quality and acceptance of three-dimensional digital geological and hydrodynamic models submitted by subsoil users as part of technical projects for the development of hydrocarbon 
deposits for consideration by the Central Commission for the Development of Rosnedra for hydrocarbons. Adopted at an expanded meeting of the Central Commission for the Development of Rosnedra for hydrocarbon raw materials dated April 19, 2012, no. 5370, comes into force on July 1, 2012]. Moscow, 2012.

26. Reglament svodnogo biznes-protsessa OP_00_08 "Integrirovannoe modelirovanie" v OOO "LUKOIL-PERM"”. Vveden $\mathrm{v}$ deistvie $\mathrm{v}$ OOO "LUKOIL-PERM"” Prikazom a-835 ot 30.03.2018 g. [Regulations for the consolidated business process OP_00_08 "Integrated Modeling" at LLC LUKOIL-PERM. Put into effect at LLC LUKOIL-PERM by Order a-835 of March 30, 2018]. Perm, 2018.

27. Sekretarev Iu.A., Miatezh T.V., Moshkin B.N. Matematicheskaia model' upravleniia funktsionirovaniem generiruiushchei kompanii v sovremennykh usloviiakh [Mathematical model for controlling generation company functioning under modern conditions]. Izvestiia Tomskogo politekhnicheskogo universiteta. Inzhiniring georesursov, 2018, vol. 329, no. 2, pp. 146-158.

28. Avrunev E.I., Chernov A.V., Dubrovskii A.V., Komissarov A.V., Pasechnik E.Iu. Tekhnologicheskie aspekty postroeniia 3Dmodeli inzhenernykh sooruzhenii $\mathrm{v}$ gorodakh arkticheskogo regiona Rossiiskoi Federatsii [Technological aspects of constructing 3D-model of engineering structures in the cities of the $\mathrm{RF}$ Arctic Region]. Izvestiia Tomskogo politekhnicheskogo universiteta. Inzhiniring georesursov, 2018, vol. 329, no. 7, pp. 131-137.

29. Romanovskii R.V. Primenenie metodov komp'iuternogo modelirovaniia zon zatopleniia pri maksimal'nykh raschetnykh urovniakh vody dlia resheniia proektnykh zadach pri rekul'tivatsii narushennykh zemel', a takzhe proektirovanii zdanii i sooruzhenii vblizi vodnykh ob"ektov [Application of computer modeling methods of flood zones at maximum design water levels for solving project tasks in the disturbed lands recultivation and design of buildings and facilities near water bodies]. Izvestiia Tomskogo politekhnicheskogo universiteta. Inzhiniring georesursov, 2019, vol. $330, \quad$ no. $2, \quad$ pp. $186-201$. DOI: $10.18799 / 24131830 / 2019 / 2 / 119$

30. Shevkunov N.O., Zhigunova A.V., Shevkunova A.V. Kachestvennaia transformatsiia metodov otsenki effektivnosti investitsionnykh proektov neftedobychi [Qualitative transformation of assessment methods of investment projects efficiency in oil production]. Izvestiia Tomskogo politekhnicheskogo universiteta. Inzhiniring georesursov, 2017, vol. 328, no. 4, pp. 67-74.

31. Mohammed K. Almedallah, Stuart D.C. Walsh Integrated well-path and surfacefacility optimization for shallow-water oil and gas field developments. Journal of Petroleum Science and Engineering, 2019, vol. 174, pp. 859-871. DOI: $10.1016 /$ j.petrol.2018.11.025

32. Cao Zhigang, Li Peichao, Li Qingyu, $\mathrm{Lu}$ Detang Integrated workflow of temperature transient analysis and pressure transient analysis for multistage fractured horizontal wells in tight oil reservoirs. International Journal of Heat and Mass Transfer, 2020, vol. 158. Article 119695. DOI: 10.1016/j.ijheatmasstransfer.2020.119695

33. Wygrala B.P. Integrated computeraided basin modeling applied to analysis of hydrocarbon generation history in a Northern Italian oil field. Organic Geochemistry in Petroleum Exploration, 1988, pp. 187-197. DOI: $10.1016 / 0146-6380(88) 90039-3$

34. Rodrigues H.W.L., Prata B.A., Bonates T.O. Integrated optimization model for location and sizing of offshore platforms and location of oil wells. Journal of Petroleum Science and Engineering, 2016, vol. 145, pp. 734-741. DOI: 10.1016/j.petrol.2016.07.002

35. Neshich S., Streletskaia V.V. Integrirovannyi podkhod pri obrashchenii $\mathrm{i}$ obratnoi zakachke poputno dobyvaemoi vody [An integrated approach for produced water treatment and injection]. Georesursy, 2018, vol. 20 , no. 1 , pp. 25-31. DOI: $10.18599 /$ grs.2018.1.25-31 
36. Stoliarov V.E., Eremin N.A. Optimizatsiia protsessov dobychi gaza pri primenenii tsifrovykh tekhnologii [The optimization of the gas production processes by the application of the digital technologies]. Geologiia, geofizika $i$ razrabotka neftianykh $i$ gazovykh mestorozhdenii, 2018, no. 6, pp. 54-61. DOI: $10.30713 / 2413-5011-2018-6-54-61$

37. Longxin M.U., Zifei F.A.N., Anzhu X.U. Development characteristics, models and strategies for overseas oil and gas fields. Petroleum Exploration and Development, 2018, vol. 45, iss. 4, pp. 735-744. DOI: 10.11698/PED.2018.04.14

38. Mullagalin I.Z., Khatmullina E.I. Nekotorye aspekty modelirovaniia pri planirovanii i analize razrabotki [Some aspects of modeling in the planning and analysis of development]. Georesursy, 2018, vol. 20 , no. 3 , pp. 165-167. DOI: $10.18599 /$ grs.2018.3.165-167

39. Bobb I.F. Mezhdunarodnyi opyt sozdaniia neftegazovykh IT-tekhnologii dlia modelirovaniia mestorozhdenii [International experience of E\&P software solutions development]. Georesursy, 2018, vol. 20, no. 3, pp. 193-196. DOI: $10.18599 /$ grs.2018.3.103-196

40. Eremin N.A., Stoliarov V.E. O tsifrovizatsii protsessov gazodobychi na pozdnikh stadiiakh razrabotki mestorozhdenii [On the Digitalization of Gas Production in the Late Stages of Field Development]. SOCAR Proceedings, 2020, no. 1, pp. 59-69. DOI: $10.5510 / O G P 20200100424$

41. Petrenko V.E., Mirzov D.A., Chernikov B.V., Ibragimov I.E., Arkhipov O.L., Remizov A.E. Kontseptsiia sozdaniia informatsionnogo obespecheniia proektov osvoeniia neftegazovykh resursov kontinental'nogo shel'fa [The concept of creating information support for continental shelf oil and gas fields development projects]. SOCAR Proceedings, 2019, no. 4, pp. 73-80. DOI: $10.5510 / O G P 20190400414$

42. Karp A.N., Krivolapova M.V., Palamarchuk I.V., Gulevich I.V. Primenenie kontseptual'nogo podkhoda $\mathrm{k}$ obustroistvu neftegazovogo aktiva na primere Imilorskogo mestorozhdeniia [Application of the conceptual approach to the development of an oil and gas asset on the example of the Imilor deposit]. Geologiia, geofizika $i$ razrabotka neftianykh $i$ gazovykh mestorozhdenii, 2020, no. 2 (338), pp. 69-75. DOI: $10.30713 / 2413-5011-2020-2(338)-69-75$

43. Goncharova O.R., Kozlov S.V. Povyshenie effektivnosti razrabotki gazoneftianykh (neftegazovykh) zalezhei na osnove podbora optimal'nykh proektnykh reshenii dlia mestorozhdenii Permskogo kraia [Enhancing the efficiency of gas-oil (oil-gas) deposits development based on selection of optimal engineering solutions for Perm Region fields]. Vestnik Permskogo natsional'nogo issledovatel'skogo politekhnicheskogo universiteta. Geologiia. Neftegazovoe $i$ gornoe delo, 2020, vol. 20 , no. $1, \quad$ pp. 88-100. DOI: $10.15593 / 2224-9923 / 2020.1 .8$

44. Aliguliev R.M., Fataliev T.Kh., Mekhtiev Sh.A. Promyshlennyi internet veshchei: evoliutsiia avtomatizatsii $\mathrm{v}$ neftegazovom komplekse [Industrial Internet of Things: the evolution of automation in the oil and gas complex]. SOCAR Proceedings, 2019, no. 2, pp. 66-71. DOI: $10.5510 / O G P 20190200391$

45. Rogachev M.K., Mukhametshin V.V., Kuleshova L.S. Povyshenie effektivnosti ispol'zovaniia resursnoi bazy zhidkikh uglevodorodov $\mathrm{v}$ iurskikh otlozheniiakh Zapadnoi Sibiri [Improving the efficiency of using resource base of liquid hydrocarbons in Jurassic deposits of Western Siberia]. Zapiski gornogo instituta, 2019, vol. 240, pp. 711-715. DOI: 10.31897/PMI.2019.6.711

\section{Библиографический список}

1. Karl W. Bandilla, Bo Guo, Michael A. Celia Applicability of vertically integrated models for carbo storage modeling in structured heterogeneous domains // Energy Procedia. - 2017. - Vol.114. - P. 3312-3321. DOI: $10.1016 /$ j.egypro.2017.03.1463

2. Towars the development of an integrated modelling framework underpinned by mineralogy / S. Ntlhabane, M. Becker, 
E. Charikinya, M. Voigt, R. Schouwstra, D. Bradshaw // Minerals Engineering. 2018. - Vol. 116. - P. 123-131. DOI: 10.1016/j.mineng.2017.09.013

3. Интегрированное моделирование инструмент повышения качества проектных решений для разработки нефтяных оторочек многопластовых нефтегазоконденсатных месторождений / Р.Т. Апасов, И.Л. Чамеев, А.И. Варавва, О.С. Верниковская, А.Р. Ильясов, В.И. Вирт // Нефтяное хозяйство. 2018. - № 12. - C. 46-49. DOI: 10.24887/00282448-2018-12-46-49

4. Мониторинг разработки месторождений с использованием интегрированного гидродинамического моделирования / А.В. Колмаков, В.А. Маришкин, А.С. Бордзиловский, В.Л. Терентьев, К.М. Федоров // Нефтяное хозяйство. - 2012. - № 7. C. $100-102$.

5. An integrated simulation model for analyzing electricity and gas systems / Burcin Cakir Erdener, Kwabena A. Pambour, Ricardo Bolado Lavin, Berna Dengiz // International journal of electrical power and energy systems. 2014. - Vol.61. - P. 410-420. DOI: $10.1016 /$ j.ijepes.2014.03.052

6. An integrated model for asphaltene deposition in wellbores/pipelines above bubble pressure / Q. Guan, A. Goharzadeh, J.C. Chai, F.M. Vargas, S.L. Biswal, W.G. Chapman, M. Zhang, Y.F. Yap // Journal of Petroleum Science and Engineering. - 2018. - Vol. 169. - P. 353-373. DOI: 10.1016/j.petrol.2018.05.042

7. Власов А.И., Андреев К.В., Кырнаев Д.В. Совершенствование разработки и эксплуатации месторождений путем применения элементов «Интеллектуального месторождения» // Нефтяное хозяйство. - 2014. - № 3. C. 68-69.

8. Практическая реализация концепции интегрированного проектирования для шельфового актива АО «Зарубежнефть» / И.С. Афанасьева, Г.Д. Федорченко, А.А. Кожемякин, В.А. Смыслов // Нефтяное хозяйство. 2016. - № 8. - С. 94-97.
9. 3D integrated numerical model for FluidStructures-Seabed Interaction (FSSI): Loosely deposited seabed foundation / Ye. Jianhong, D.-S. Jeng, A.H.C. Chan, R. Wang, Q.C. Zhu // Soil Dynamics and Earthquake Engineering. - 2017. - Vol. 92. - P. 239-252. DOI: $10.1016 /$ j.soildyn.2016.10.026

10. Modeling temperature-based oilwater relative permeability by integrating advanced intelligent models with grey wolf optimization: Application to thermal enhance oil recovery process / Nait Amar Menad, Zeraibi Noureddine, Abdolhossein Hemmati-Sarapardeh, Shahaboddin Shamshirband // Fuel. 2019. - Vol. 242. - P. 649-663. DOI: 10.1016/j.fuel.2019.01.047

11. Akhmetzianov Atlas V., Kushner Alexei G., Lychagin Valentin V. Integrable models of oil displacement // IFAC-PapersOnLine. 2015. - Vol. 48, issue 3. - P. 1264-1267. DOI: $10.1016 /$ j.ifacol.2015.06.258

12. Horsholt S., Nick H.M., Jorgensen J.B. Oil production optimization of BlackOil models by integration of Matlab and Eclipse E300 // IFAC-Papers Online. 2018. - Vol. 51, iss. 8. - P. 88-93. DOI: $10.1016 /$ j.ifacol.2018.06.360

13. Cuiwei Liu, Yuxing Li, Minghai $\mathrm{Xu}$ An integrated detection and location model for leakages in liquid pipelines // Journal of Petroleum Science and Engineering. 2019. - Vol. 175. - P. 852-867. DOI: $10.1016 /$ j.petrol.2018.12.078

14. Integrated modeling of crop production and nitrate leaching with the Daisy model / Kiril Manevski, Christen D. Borgesen, Xiaoxin Li, Mathias N. Andersen, Per Abrahamsen, Chunsheng $\mathrm{Hu}$, Soren Hansen // Methods'. - 2016. - Vol. 3. - P. 350-363. DOI: 10.1016/j.mex.2016.04.008

15. Интегрированное моделирование разработки нефтяной оторочки Песцового месторождения / И.В. Коваленко, А.Г. Выдрин, А.Ю. Семенов, А.Н. Суханов, М.В. Федоров // Нефтяное хозяйство. 2019. - № 2. - C. 49-51. DOI: 10.24887/00282448-2019-2-49-51 
16. Интегрированный подход к планированию показателей нефтегазодобывающего предприятия в АО «Зарубежнефть» / С.И. Кудряшов, И.С. Афанасьева, А.В. Дашевский, А.А. Кожемякин // Нефтяное хозяйство. - 2015. - № 12. - С. 144-148.

17. Костюченко С.В., Кудряшов С.В., Воробьев П.В. Интегрированные модели для проектирования согласованных систем добычи и сбора нефти (часть 1) // Нефтяное хозяйство. - 2003. - № 11. - С. 100-103.

18. Опыт комплексного проектирования месторождений ОАО «Самаранефтегаз» / Г.Г. Гилаев, А.Э. Манасян, А.М. Воропаев, А.Ф. Исмагилов, И.Г. Хамитов, И.И. Киреев // Нефтяное хозяйство. - 2013. - № 3. C. 54-57.

19. Интегрированное концептуальное проектирование, как инструмент системного инжиниринга / В.П. Батрашкин, Р.Р. Исмагилов, Р.А. Панов, А.Ф. Можчиль, Н.3. Гильмутдинова, Д.Е. Дмитриев // Нефтяное хозяйство. - 2016. - № 12. - С. 80-83.

20. Интегрированная модель для комплексного управления разработкой и обустройством месторождений / Р.Р. Исмагилов, Ю.В. Максимов, О.С. Ушмаев, А.Ф. Можчиль, Н.3. Гильмутдинов // Нефтяное хозяйство. 2014. - № 12. - С. 71-73.

21. Цифровой конщептуальный инжиниринг: автоматизация размещения объектов обустройства / Р.А. Панов, А.Ф. Можчиль, Д.Е. Дмитриев, П.О. Алексеев, А.В. Ельонышев, И.А. Ашихмин // Нефтяное хозяйство. 2018. - № 12. - C. 72-75. DOI: $10.24887 / 0028-$ 2448-2018-12-72-75

22. Integrated field operation and optimization / Silvya Dewi Rahmawati, Curtis Hays Whitson, Bjarne Foss, Arif Kuntadi // Journal of Petroleum Science and Engineering. - 2012. - Vol. 81. - P. 161-170. DOI: $10.1016 /$ j.petrol.2011.12.027

23. Modeling framework for integrated, Model-based development of productService systems / Hristo Apostolov, Matthias Fischer, Daniel Olivotti, Sonja Dreyer, Martin Eigner // Procedia CIRP. 2018. - Vol.73. - P. 9-14. DOI: $10.1016 /$ j.procir.2018.03.307
24. Integrated development optimization model and its solving method of multiple gas fields / Qiang Li, Haiquan Zhong, Yuan Wang, Youheng Leng, Chunqiu Guo // Petroleum Exploration and Development. 2016. - Vol. 43, issue 2. - P. 293-300. DOI: $10.1016 / S 1876-3804(16) 30033-7$

25. Временный регламент оценки качества и приемки трехмерных цифровых геологогидродинамических моделей, представляемых пользователями недр в составе технических проектов разработки месторождений углеводородного сырья на рассмотрение Центральной комиссии по разработке Роснедра по углеводородному сырью / принят на расширенном заседании Центральной комиссии по разработке Роснедра по углеводородному сырью от 19.04.2012, № 5370, вводится в действие с 01.07.2012. M., 2012.

26. Регламент сводного бизнеспроцесса OP_00_08 «Интегрированное моделирование» в ООО «ЛУКОЙЛ-ПЕРМЬ» / введен в действие в ООО «ЛУКОЙЛПЕРМЬ» Приказом а-835 от 30.03.2018 г. Пермь, 2018.

27. Секретарев Ю.А., Мятеж Т.В., Мошкин Б.Н. Математическая модель управления функционированием генерирующей компании в современных условиях // Известия Томского политехнического университета. Инжиниринг георесурсов. - 2018 . - 2 Т. 329, № 2. - C. 146-158.

28. Технологические аспекты построения 3D-модели инженерных сооружений в городах арктического региона Российской Федерации / Е.И. Аврунев, А.В. Чернов, А.В. Дубровский, А.В. Комиссаров, Е.Ю. Пасечник // Известия Томского политехнического университета. Инжиниринг георесурсов. - 2018. - Т. 329, № 7 . C. 131-137.

29. Романовский Р.В. Применение методов компьютерного моделирования зон затопления при максимальных расчетных уровнях воды для решения проектных задач при рекультивации нарушенных земель, а также проектировании 
зданий и сооружений вблизи водных объектов // Известия Томского политехнического университета. Инжиниринг георесурсов. - 2019. - Т. 330, № 2. - С. 186-201. DOI: $10.18799 / 24131830 / 2019 / 2 / 119$

30. Шевкунов Н.О., Жигунова А.В., Шевкунова трансформация методов оценки эффективности инвестиционных проектов нефтедобычи // Известия Томского политехнического университета. Инжиниринг георесурсов. - 2017. - Т. 328, № 4. C. 67-74.

31. Mohammed K. Almedallah, Stuart D.C. Walsh Integrated well-path and surfacefacility optimization for shallow-water oil and gas field developments // Journal of Petroleum Science and Engineering. 2019. - Vol.174. - P. 859-871. DOI: 10.1016/j.petrol.2018.11.025

32. Integrated workflow of temperature transient analysis and pressure transient analysis for multistage fractured horizontal wells in tight oil reservoirs / Zhigang Cao, Peichao Li, Qingyu Li, Detang Lu // International Journal of Heat and Mass Transfer. - 2020. - Vol. 158. Article 119695. DOI: 10.1016/j.ijheatmasstransfer.2020.119695

33. Wygrala B.P. Integrated computeraided basin modeling applied to analysis of hydrocarbon generation history in a Northern Italian oil field // Organic Geochemistry in Petroleum Exploration. - 1988. - P. 187-197. DOI: $10.1016 / 0146-6380(88) 90039-3$

34. Rodrigues H.W.L., Prata B.A., Bonates T.O. Integrated optimization model for location and sizing of offshore platforms and location of oil wells // Journal of Petroleum Science and Engineering. 2016. - Vol. 145. - P. 734-741. DOI: $10.1016 /$ j.petrol.2016.07.002

35. Нешич С., Стрелецкая В.В. Интегрированный подход при обращении и обратной закачке попутно добываемой воды // Георесурсы. 2018. - T. 20, № 1. - С. 25-31. DOI: $10.18599 /$ grs.2018.1.25-31
36. Столяров В.Е., Еремин Н.А. Оптимизация процессов добычи газа при применении цифровых технологий // Геология, геофизика и разработка нефтяных и газовых месторождений. 2018 . - № $6 . \quad$ - C. 54-61. DOI: $10.30713 / 2413-5011-2018-6-54-61$

37. Longxin M.U., Zifei F.A.N., Anzhu X.U. Development characteristics, models and strategies for overseas oil and gas fields // Petroleum Exploration and Development. - 2018.

Vol. 45, iss. 4. - P. 735-744. DOI: 10.11698/PED.2018.04.14

38. Муллагалин И.3., Хатмуллина Е.И. Некоторые аспекты моделирования при планировании и анализе разработки // Георесурсы. - 2018. - Т. 20, № 3. - С. 165-167. DOI: $10.18599 /$ grs.2018.3.165-167

39. Бобб И.Ф. Международный опыт создания нефтегазовых IT-технологий для моделирования месторождений // Георесурсы. - 2018. - Т. 20, № 3. - С. 193-196. DOI: $10.18599 /$ grs.2018.3.103-196

40. Еремин Н.А., Столяров В.Е. О цифровизации процессов газодобычи на поздних стадиях разработки месторождений // SOCAR Proceedings. - 2020. - № 1. - C. 59-69. DOI: $10.5510 / O G P 20200100424$

41. Концепция

информационного обеспечения проектов освоения нефтегазовых ресурсов континентального шельфа / В.Е. Петренко, Д.А. Мирзов, Б.В. Черников, И.Э. Ибрагимов, О.Л. Архипов, А.Е. Ремизов // SOCAR Proceedings. - 2019. - № 4. - C. 73-80. DOI: $10.5510 / O G P 20190400414$

42. Применение концептуального подхода к обустройству нефтегазового актива на примере Имилорского месторождения / А.Н. Карп, М.В. Криволапова, И.В. Паламарчук, И.В. Гулевич // Геология, геофизика и разработка нефтяных и газовых месторождений. 2020. - № 2 (338). - C. 69-75. DOI: $10.30713 / 2413-5011-2020-2(338)-69-75$

43. Гончарова О.Р., Козлов С.В. Повышение эффективности разработки газонефтяных (нефтегазовых) залежей 
на основе подбора оптимальных проектных решений для месторождений Пермского края // Вестник Пермского национального исследовательского политехнического университета. Геология. Нефтегазовое и горное дело. 2020. - T. 20, № $1 . \quad$ - C. 88-100. DOI: $10.15593 / 2224-9923 / 2020.1 .8$

44. Алигулиев Р.M., Фаталиев Т.Х., Мехтиев Ш.А. Промышленный интернет вещей: эволюция автоматизации в нефтегазовом комплексе // SOCAR Proceedings. - 2019. - № 2. C. 66-71. DOI: 10.5510/OGP20190200391

45. Рогачев М.К., Мухаметшин В.В., Кулешова Л.С. Повышение эффективности использования ресурсной базы жидких углеводородов в юрских отложениях Западной Сибири // Записки горного института. - 2019. - Т. 240. - С. 711-715. DOI: 10.31897/PMI.2019.6.711

Please cite this article in English as:

Filippov E.V., Chumakov G.N., Ponomareva I.N., Martyushev D.A. Application of Integrated Modeling in the Oil and Gas Industry. Perm Journal of Petroleum and Mining Engineering, 2020, vol.20, no.4, pp.386-400. DOI: $10.15593 / 2712-8008 / 2020.4 .7$

Просьба ссылаться на эту статью в русскоязычных источниках следующим образом:

Применение интегрированного моделирования в нефтегазовой отрасли / Е.В. Филиппов, Г.Н. Чумаков, И.Н. Пономарева, Д.А. Мартюшев // Недропользование. - 2020. - Т.20, №4. - С.386-400. DOI: $10.15593 / 2712-8008 / 2020.4 .7$ 